\title{
Unexpected presence of Fagus orientalis complex in Italy as inferred from 45,000-year-old DNA pollen samples from Venice lagoon Donatella Paffetti ${ }^{1}$, Cristina Vettori ${ }^{2}$, David Caramelli ${ }^{3}$, Cristiano Vernesi ${ }^{4}$, Martina Lari ${ }^{3}$, Arturo Paganelli ${ }^{5}$, Ladislav Paule ${ }^{6}$ and Raffaello Giannini*1,2
}

\begin{abstract}
Address: ${ }^{1}$ Department of Environmental and Forestry Technologies and Sciences, University of Florence, Via San Bonaventura 13, 50145 Florence, Italy, ${ }^{2}$ Plant Genetics Institute, National Research Council, Via Madonna del Piano 10, 50019, Sesto Fiorentino (FI), Italy, ${ }^{3}$ Dipartimento di Biologia Animale e Genetica, Laboratorio di Antropologia, University of Florence, Via del Proconsolo 12, 50122 Firenze, Italy, ${ }^{4}$ Centro Ecologia Alpina, Viote del Monte Bondone, 38040 Trento, Italy, ${ }^{5}$ Department of Biology, University of Padova, Via U. Bassi 58/B, I-35121, Padova, Italy and ${ }^{6}$ Faculty of Forestry, Technical University, SK-96053 Zvolen, Slovakia

Email: Donatella Paffetti - donatella.paffetti@unifi.it; Cristina Vettori - cristina.vettori@igv.cnr.it; David Caramelli - david.caramelli@unifi.it; Cristiano Vernesi - vernesi@cealp.it; Martina Lari - martina.lari@unifi.it; Arturo Paganelli - arturo.paganelli@unipd.it;

Ladislav Paule - paule@vsld.tuzvo.sk; Raffaello Giannini* - raffaello.giannini@unifi.it

* Corresponding author
\end{abstract}

from Second Congress of Italian Evolutionary Biologists (First Congress of the Italian Society for Evolutionary Biology)

Florence, Italy. 4-7 September 2006

Published: 16 August 2007

BMC Evolutionary Biology 2007, 7(Suppl 2):S6 doi:10.1 I86/147| I-2 I48-7-S2-S6

This article is available from: http://www.biomedcentral.com/I47I-2I48/7/S2/S6

(C) 2007 Paffetti et al; licensee BioMed Central Ltd.

This is an open access article distributed under the terms of the Creative Commons Attribution License (http://creativecommons.org/licenses/by/2.0),

which permits unrestricted use, distribution, and reproduction in any medium, provided the original work is properly cited.

\begin{abstract}
Background: Phylogeographic analyses on the Western Euroasiatic Fagus taxa (F. orientalis, $F$. sylvatica, F. taurica and F. moesiaca) is available, however, the subdivision of Fagus spp. is unresolved and there is no consensus on the phylogeny and on the identification (both with morphological than molecular markers) of Fagus Eurasiatic taxa.

For the first time molecular analyses of ancient pollen, dated at least 45,000 years ago, were used in combination with the phylogeny analysis on current species, to identify the Fagus spp. present during the Last Interglacial period in Italy.

In this work we aim at testing if the trnL-trnF chloroplast DNA (cpDNA) region, that has been previously proved efficient in discriminating different Quercus taxa, can be employed in distinguishing the Fagus species and in identifying the ancient pollen.

Results: 86 populations from 4 Western Euroasistic taxa were sampled, and sequenced for the trnL-trnF region to verify the efficiency of this cpDNA region in identifying the Fagus spp.. Furthermore, Fagus crenata (2 populations), Fagus grandifolia (2 populations), Fagus japonica, Fagus hayatae, Quercus species and Castanea species were analysed to better resolve the phylogenetic inference.

Our results show that this cpDNA region harbour some informative sites that allow to infer relationships among the species within the Fagaceae family. In particular, few specific and fixed mutations were able to discriminate and identify all the different Fagus species.
\end{abstract}


Considering a short fragment of 176 base pairs within the trnL intron, 2 transversions were found able in distinguishing the $F$. orientalis complex taxa ( $F$. orientalis, $F$. taurica and $F$. moesiaca) from the remaining Fagus spp. (F. sylvatica, F. japonica, F. hayataea, F. crenata and F. grandifolia). This permits to analyse this fragment also in ancient samples, where DNA is usually highly degraded.

The sequences data indicate that the DNA recovered from ancient pollen belongs to the $F$. orientalis complex since it displays the informative sites characteristic of this complex.

Conclusion: The ancient DNA sequences demonstrate for the first time that, in contrast to current knowledge based on palynological and macrofossil data, the $F$. orientalis complex was already present during the Tyrrhenian period in what is now the Venice lagoon (Italy).

This is a new and important insight considering that nowadays West Europe is not the natural area of Fagus orientalis complex, and up to now nobody has hypothesized the presence during the Last Interglacial period of $F$. orientalis complex in Italy.

\section{Background}

Fossil analogs of modern Fagaceae family are well represented in the Northern Hemisphere, indicating long-term presence and differential patterns of species diversification throughout the Tertiary and Quaternary period [1-3].

In Italy during the Tyrrhenian, the last interglacial period which started around 130,000 years ago, palaeontological and palynological data support the existence in the Veneto-Po Plain of a mixed forest of Colchic type dominated by fir-trees (including Abies nordmanniana (Steven) Spach) and pine-trees, together with the broad-leaved trees Zelkova Spach, Quercus L., Ulmus L., Tilia L., Carpinus L., Corylus L., Fagus L., Betula L. and Castanea Miller [4-6].

Although a complete agreement has not been reached, most authors indicate that the Fagaceae family includes nine genera: Fagus L., Castanea L., Castanopsis Spach., Chrysolepis Hjelmquist, Colombobalanus (Lozano, Hdz-C. \& Henao) Nixon \& Crepet, Formanodendron (Camus) Nixon \& Crepet, Lithocarpus Bl., Quercus L., and Trigonobalanus Forman [7]. Most genera are in temperate forests of the Northern Hemisphere, and they show a hot-spot of diversity in tropical zones of the Southern-East Asia [7].

The Fagaceae family has been extensively studied at the genetic $[8,9]$, biogeographic and phylogeographic [10-19] level. Thanks to macrofossils richness several taxonomic and macroevolutionary studies have been performed as well [20-27]. Despite this, the taxonomic subdivision in the Fagaceae family is still controversial, due to the small number of prominent characteristics of the fruit and floral [28-30].

The traditional classification of beech in Western Eurasia recognizes one species, $F$. sylvatica with two subspecies $F$. s. sylvatica and F. s. orientalis, and two intermediary types, F. moesiaca and F. taurica [31,32].
Fagus sylvatica L. is distributed in western, central and southern Europe with marginal and isolated occurrences in England, and Scandinavia. The natural range of F. orientalis is Asia Minor, the Amanus Mts. (Syria), the Elburz Mts. (Iran), and Caucasus. Isolated occurrences of this taxa outside the natural range were found in eastern Serbia, in Macedonia, in Banate, in Moldova, in Dobrudja, and in central Bulgaria. Contact zones between the natural ranges of both taxa are reported in northern Greece and Bulgaria [33]. Authors disagree about the taxonomic position of Fagus taurica Popl. (Crimea) and Fagus moesiaca Czecz. (Balkan). F. taurica is considered by some authors as the intermediate form between F. sylvatica and $F$. orientalis, and by others as an independent species. Similar doubts regard the taxonomy of $F$. moesiaca considered an independent species or, most frequently, the subspecies of F. sylvatica [33]. The description of these taxa has been mainly based on the morphological traits of leaves [33].

Standing the difficulties in discriminating closely related taxa and the overlapping of their natural range, the molecular data by Manos and Stanford [34] provided the most reliable phylogenetic reconstruction of Fagaceae family. However, they presented limited data from European taxa, which have been traditionally included in various morphologically distinct groups. Also Denk and colleagues $[32,35]$ tried to combine morphological and molecular data to resolve the controversy within the western Eurasiatic taxa without succeeding.

From these statements it is clear that is still controversial whether the two taxa (F. sylvatica and F. orientalis) are really separated, and whether the intermediates are two different taxonomic units (F. taurica and F. moesiaca).

Analysing populations of the Western Eurasiatic taxa $F$. sylvatica ( 38 populations), F. moesiaca (6 populations), $F$. taurica (5 populations) and F. orientalis (31 populations), 
using the trnL-trnF chloroplast DNA (cpDNA) sequence (composed: $\operatorname{trn} \mathrm{L}$ intron, second $\operatorname{trn} \mathrm{L}$ exon, and partial sequence of the trn L-trn $\mathrm{F}$ intergenic spacer), that has been previously proved efficient in discriminating Quercus entities [36], we aim at: (i) inferring relationships among the species within the Fagaceae family; (ii) identifying the Western Eurasiatic taxa; (iii) combining, for the first time, phylogeny analyses on present Fagus spp. with molecular analyses of pollen from Italian fossil specimens as old as about 45,000 yrs before present.

In addition $F$. crenata (2 populations), F. grandifolia (2 populations) F. japonica [GenBank: AB046521], F. hayatae [GenBank: AB046522], Quercus spp. and Castanea spp. were analysed to better resolve the phylogeny inference (see Additional file 1).

\section{Results and discussion \\ Identification of Fagaceae family and species}

The phylogenetic relationship among and within Quercus, Castanea and Fagus genera belonging to Fagaceae family have been inferred analysing the trnL-trn $\mathrm{F}$ cpDNA region in several species and in several individuals (see Additional file 1).

The entire trnL-trnF cpDNA ranged from 797 bp in C. crenata Sieb. to $655 \mathrm{bp}$ in F. crenata Blume. The multiple alignment of the trn $\mathrm{L}-\mathrm{trn} \mathrm{F}$ region among the different species resulted in a sequence 889 bp long; the trn $\mathrm{L}$ intron had a length of $505 \mathrm{bp}$, the second trnL exon had a length of $50 \mathrm{bp}$, and the $\operatorname{trn} \mathrm{L}-\operatorname{trn} \mathrm{F}$ partial intergenic spacer had a length of $334 \mathrm{bp}$ (see Additional file 2).

The trn L intron belonging to intron I group is interesting for RNA secondary structure that permits to conserve active form for "autosplicing". These introns have different nucleotide primary structure, but the same secondary structure is conserved from cyanobacteria, to algae, and to plant. The conserved nucleotide regions are short four sequences named $\mathrm{P}, \mathrm{Q}, \mathrm{R}$, and $\mathrm{S}$ [37]. These sequences are always present in the same order within intron, but the distance among contiguous elements range from few to hundred nucleotides [37]. The nucleotide conserved sequences in trnL intron were identified in Quercus genus by Paffetti et al [36]: P (TTCAGAGAAAC), Q (AATCCTGAGC), R (GTGCAGAGACTCAA) and $S$ (AAGATAGAGTCC). In the present work the same sequences have been found in Castanea and Fagus genera.

The intron and exon of $\operatorname{trn} \mathrm{L}$ show few nucleotides changes within Fagaceae family, particularly among the Castanea and Quercus genera according to the low rate of chloroplast DNA variation within this family, as previously shown for other cpDNA regions by several authors [7,38$40]$. The Fagus genus is divergent from the other genera due to an insertion of 41 nucleotides within the intron region (see Additional file 2).

The Kimura-81 model [41] with a proportion of invariant sites (0.61) and a rate variation among sites ( $\alpha$ value of the $\gamma$ distribution equal to 0.74 ) was selected as best-fit model of sequence evolution and then employed in Maximum Likelihood (ML) and Bayesian analyses (BI). Since trees recovered by the three different methods, Maximum Parsimony (MP), ML and BI, substantially display the same topology, we show only the ML tree (Figure 1).

The different Fagus species were grouped in the same unresolved cluster, providing no information about their phylogenetic relationships. High bootstrap and Bayesian posterior probability values are present only in the part of the tree involving the separation between Castanea and Quercus genera and inside the cluster of Castanea species.

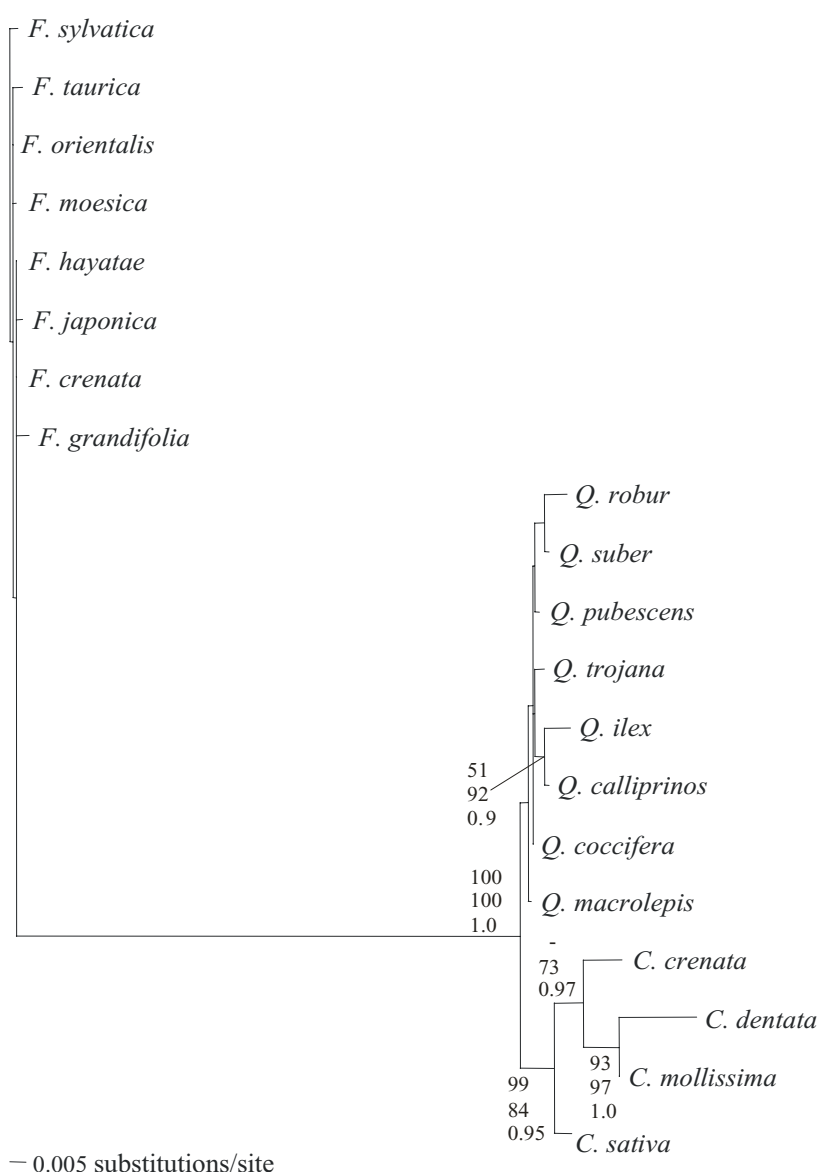

Figure I

Phylogenetic analysis. Maximum Likelihood phylogenetic tree of present time Fagaceae family based on trnL-trnF cpDNA sequences. 
The phylogenetic reconstruction shows a subdivision of the Fagaceae family in Fagoideae, Quercoideae and Castanoideae subfamily according to traditional systematic and to data obtained by Manos and Steele [39] analysing mitochondrial matK gene, but in contrast with the results obtained by Nixon and Crepet [24] with macrofossil data.

Moreover, the results confirm a recent monophyletic origin of the Fagoideae subfamily and common origin (sister subfamily) of the Quercoideae and Castanoideae confirming data obtained by Manos and Steele [39].

The region in the alignment ranging from position 1 to 180 can distinguish the genera (see Additional file 2). Particularly, the Fagus genus is distinguished from Quercus and Castanea genera by four transversion (at sites 54, 78, 166 and 178) and by one transition at site 152 . Moreover, the Castanea genus is distinguished from Quercus genus by one transversion at site 159 .

A sequence comparative analysis of the $\operatorname{trn} \mathrm{L}-\operatorname{trn} \mathrm{F}$ cpDNA region has been done among all the Fagus spp. considered (see Additional file 1).

The entire region ranged from $660 \mathrm{bp}$ in F. sylvatica and in F. grandifolia Ehrh., to $655 \mathrm{bp}$ in F. crenata. The trnL intron harbour some informative sites that allow to discriminate the different species inside the genus, with the intergenic region showing a higher variability at the intraspecific level. These data confirmed the results of previous studies on the genus Quercus, highlighting the usefulness of this sequence for taxa identification [36].

These are the most informative sites: (i) a $41 \mathrm{bp}$ insertion (between positions 388 and 428) in the intron, and a 190 bp deletion (between positions 618 and 807) in the intergenic region characterise the genus Fagus; (ii) two transversions (site 116 and site 118 ) in the intron identify $F$. sylvatica; (iii) two transitions (site 116 and site 118) in the intron identify F. grandifolia; (iv) one transition (site 132) in the intron identifies F. japonica Bl.; (v) one transversion (site 439) in the intron identifies F. moesiaca; and (vi) two transitions (site 593 and site 596) in the intergenic identify F. taurica (see Additional file 2). The transversion (A/ C) at site 140 is particularly interesting as it discriminates the western Eurasiatic taxa from the others. It is to notice that all the European taxa have an A, and the Asiatic species have a C. As also the other genus Quercus and genus Castanea have a C in the site 140, this is indicating that this base was present in the common ancestor of the genus Fagaceae, and that its mutation to A occurred in European Fagus more recently. Therefore, the Asiatic species are more ancient than the European ones. Moreover, F. orientalis seems to be originated early from the other
European groups, as it presents an identical sequence to the Asiatic ones except for the site 140.

It is possible to distinguish the $F$. grandifolia species from Asiatic and western Eurasiatic taxa, and the Asiatic species from western Eurasiatic taxa; among the latter F. orientalis, F. moesiaca, F. taurica and F. sylvatica can be identified, and $F$. orientalis can be regarded as the ancestral species in European beech.

In comparison to previous works, the region analysed in this study is able to discriminate the different Fagus species as some mutation are fixed and specific for each Fagus species. Nevertheless, we also find that within Fagus spp. the differences are very few suggesting that speciation process within this group might be still in progress $[32,35]$.

\section{Identification of ancient DNA}

It is well known that DNA degradation processes pose serious limits to the length of the fragments that can be retrieved from ancient specimens [42]: only stretches of DNA less than 200 bp can be confidently analysed. Therefore, considering the age of our sample, we decided to amplify from ancient samples the trnL-trnF region ranging from site 37 to site 215 , namely the region that proved useful to distinguish among the different genera (Quercus, Castanea and Fagus) and also among the main taxa (F. sylvatica, F. orientalis, F. japonica, F. grandifolia) inside the Fagus genus.

This region was first amplified by real-time PCR (qPCR) to estimate the copy number of cpDNA in ancient sample for the assessment of its authenticity.

A post-amplification melting curve analysis was carried out to verify that artefactual products (primer dimers, non-specific products) were not present within each reaction. A unique melting curve characteristic of our DNA fragment (different dissociation curves are obtained if different size and base composition fragments are present, as also showed by Pruvost and Geigl [43]) was obtained indicating that the reaction was problem free.

We determined that the initial amount of genuine chloroplast molecules in the fossil sample is about $59,900 \mathrm{~mol}$ ecules $/ \mu \mathrm{l}$.

One pollen grain contains about 10,000 cpDNA molecules, and five Fagus pollen grains are present in $1 \mu \mathrm{l}$ of our sample (Paganelli, personal communication), so the estimated copy number is of 50,000 genomes/ $\mu \mathrm{l}$; a value very similar to the estimation made by qPCR. Therefore, we can say that our result is reliable enough for a study based on ancient DNA amplification [42]. 
The sequences of $176 \mathrm{bp}$ obtained from fossil material, dated older than 45,000 years before present (BP) and collected near Bocca di Malamocco (Venice, Italy) (see Material and Method), belong to Fagus genus, since they display the informative transversions at sites 18 and 42 . All the 45 clones analysed showed the same nucleotide sequences. The mutations present in these sequences are characteristic of the Western Eurasiatic group due to the presence of the transversion at site 105 position. Moreover, these sequences do not belong to $F$. sylvatica since they show transversions (A/T) at both sites 81 and 83 (Figure 2).

Therefore, the results show that $F$. orientalis complex ( $F$. orientalis, F. taurica, F. moesiaca) and not F. sylvatica was present in Val Padana (Italy) 45,000 years BP. These data confirm the palynological data obtained by Calderoni and colleagues [44], who was not able to discriminate among the Fagus spp. for the limitation of the methods. Therefore, our molecular data add new crucial information to the palynological data.

[
[
Fossil material $\mathbf{1 - 4 5}$
Fossil material $\mathbf{3 - 4 5}$
F. sylvatica
F. taurica
F. orientalis
F. moesica
F. hayatae
F. japonica
F. Crenata
F. grandifolia
Q. robur
Q. pubescens
Q. Suber
Q. trojana
Q. macrolepis
Q. ilex
Q. Coccifera
Q. Calliprinos
C. Crenata
C. dentata
C. mollissima
C. sativa

111 1111111] $13458890123344457]$ 8524137574 1837998] CAGAAAAAAT GTACACC

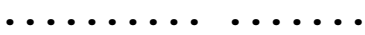
$\ldots \ldots \ldots \ldots \ldots$ ...тT....... $\ldots \ldots \ldots \ldots \ldots$ $\ldots \ldots \ldots \ldots \ldots$ $\ldots \ldots \ldots \ldots \ldots$ $\ldots \ldots \ldots$........ $\ldots \ldots$ GC....... $\ldots \ldots \ldots$........ ...GG.C........ AGC..... CGG T.CACAG A.C..... CGG T.CACAG A.C..... CGG T.CACAG A.CG...CGG T.CACAG A.CG...CGG T.CACAG A.CG...CGG T.CACAG A.CG... CGG T. CACAG A.CG...CGG T.CACAG A.CG...CG. T.CACAG A.CG...CG. T.CACAG A.CG...CG. T.CACAG A.CG...CG. T.CACAG

\section{Figure 2}

Informative sites. Variable informative sites among Fagaceae species analysed and fossil material.

\section{Euroasiatic Fagus taxa and ancient pollen grouping}

The same 37-215 cpDNA region was used to construct a statistical parsimony network containing both ancient and modern samples of F. sylvatica, F. moesiaca, F. taurica and F. orientalis (Figure 3). Only 12 different haplotypes were recovered out of the 81 specimens analysed ( 80 modern plus the ancient specimen) (see Additional file 3).

The network clearly shows that two major groups, separated by at least three mutational steps, can be identified. The cluster A, comprising haplotypes from 1 to 9, is represented by the F. orientalis, F. moesiaca, F. taurica samples, plus the ancient specimens and some F. sylvatica samples. The cluster B, with haplotypes from 10 to 12 , is formed by samples referred only to F. sylvatica taxa.

It is evident that the cluster B is homogeneous confirming previously data on F. sylvatica in western Europe [32].

$\mathbf{A}$

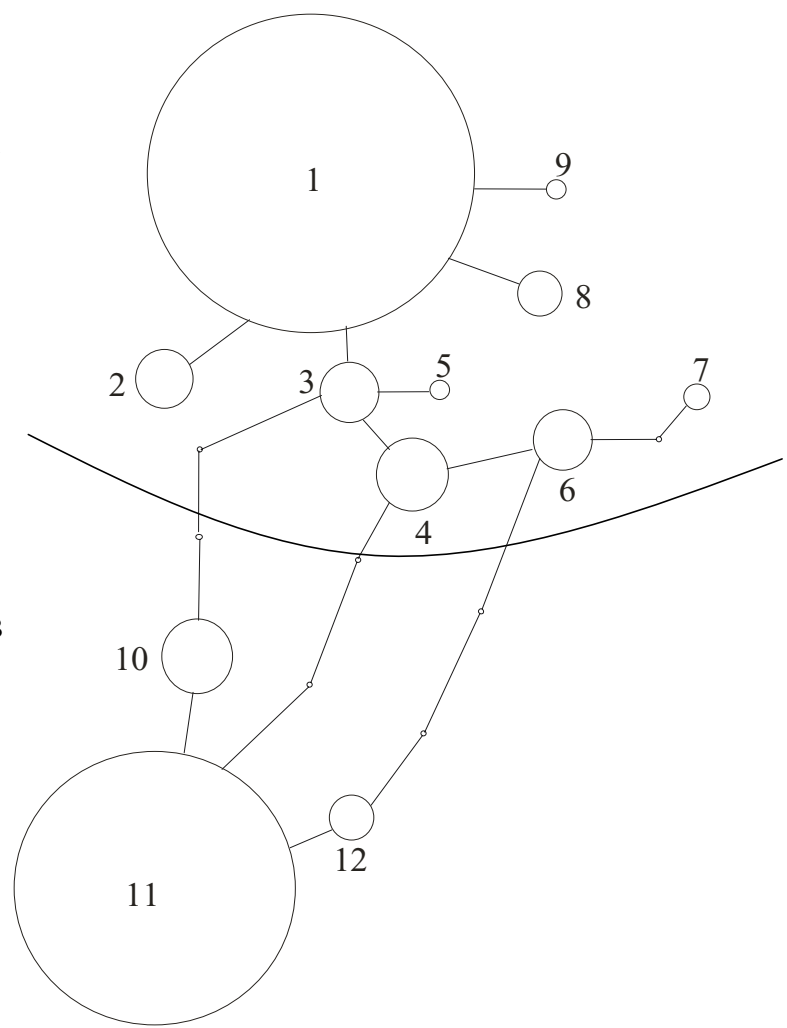

Figure 3

Haplotype network. Haplotype network for the chloroplast DNA haplotypes of Fagus spp. and of fossil material. Each line in the network represents a single mutation change. An haplotype is represented by a circle, and each haplotype is identify by a number. Empty circles indicate intermediate haplotypes that are not present in the sample but are necessary to link all observed haplotypes to the network. 
The heterogeneity of cluster $\mathrm{A}$ is due to the presence of a mix of taxa and it can be explained, at a first attempt, by the length of the sequence used in the construction of the network, which does not contain the informative sites necessary to distinguish $F$. taurica and $F$. moesiaca from $F$. orientalis.

Another source of apparent incongruence is the presence, in this cluster A, of some populations, morphologically described as F. sylvatica. In effect, the sequence analysis showed that these populations have the typical sequence of the F. orientalis.

Nonetheless, some authors already pointed out that some central-south Italian populations look like the Balkans peninsula ones $[9,19]$. This seems to be the result of an ancient connection, during the Pliocene, between the Italian and Balkan peninsulas, as confirmed by previous isoenzyme analyses. This connection might have favoured gene flow and genetic admixture between the gene pool originated from the two peninsulas [9].

Considering that fossil material analysed in this study resulted belonging to the F. orientalis complex, another hypothesis can be put forward: these taxa were present in the Po valley 45,000 years BP. Therefore, we can hypothesize that during the interglacial period the $F$. orientalis complex was the dominant forest vegetation in Italian peninsula, and that the actual F. sylvatica populations (located at Foresta Umbra, Monte Taburno, Laghi di Monticchio, Monte Pecoraro, Monte Basilicò) can be considered remains of ancient populations.

Previous studies already showed that these populations are divergent from other F. sylvatica populations. In fact, the presence of unique haplotypes in central-southern populations was previously demonstrated [19].

Magri [45] suggested that beech populations might have survived during the last glacial period at different locations in the Italian peninsula, so that no clear large-scale migration trends can be recognised in southern and central Italy. The presence of populations displaying high divergence in Central-Southern Italy may be associated to the fact that beech populations persisted in these regions since the middle Pleistocene, as also suggested by Follieri and colleagues [46]. During the Saint Germain I (about $110,000-95,000$, BP), beech represented a major component of the vegetation in central Italy. Pollen data revealed that the Italian peninsula might have been an important area for the survival of beech not only during the last glaciation, but also during previous interglacial periods [45].

Our results seem to confirm these hypotheses, adding the new information that the F. orientalis complex was already present.

The sporadic occurrence of F. orientalis in Greek and Romania populations reported in previous work [9,33] can explain the presence of some of these populations in the cluster A.

Accordingly to the results of the network, we subdivided our modern samples in two groups, F. orientalis-complex (cluster A) and F. sylvatica (cluster B), comprising respectively 51 and 29 samples. Using the entire cpDNA sequence of Fagus spp., 722 bp long, we submitted these groups to specific population genetics analyses. The genetic differentiation between $F$. orientalis-complex (cluster A) and F. sylvatica (cluster B) resulted very strong with a $\Phi_{s t}$ value equal to $0.67(\mathrm{p}<0.001)$. The F. orientalis-complex (cluster A) is characterised by a value of allelic richness as three times as greater than that of $F$. sylvatica (cluster B) (Table 1). The greater genetic diversity within F. orientalis-complex (cluster A) is confirmed by another measure not strictly dependent on the number of samples being compared, such as the mean number of pairwise differences: we see that the F. orientalis-complex cluster has a value as twice as higher than that of F. sylvatica. We applied two statistical tests for neutrality, Tajima's D and Fu's Fs. Both tests gave statistically significant negative values only for the F. orientalis-complex (Table 1). Assuming neutrality selection at the locus under study, these results can be interpreted as a signature of a demographic expansion.

All these results can reinforce the hypothesis according to which $F$. orientalis is the ancestral species in European beech; as also previously hypothesize by the sequence analysis. In fact, if we consider F. sylvatica a species derived from the ancestral F. orientalis, this can partially explain its reduction in genetic variability $[47,48]$.

Table I: Haplotype network analysis.

\begin{tabular}{|c|c|c|c|c|c|c|c|c|}
\hline Group & n & $\mathbf{k}$ & $\mathbf{H}$ & Ar (20) & $\pi(\times \mid 00)$ & MPD & Fu's Fs & Tajima's D \\
\hline F. orientalis complex cluster $\mathrm{A}$ & 51 & 28 & $0.92 \pm 0.03$ & 13.75 & $0.21 \pm 0.14$ & $1.55 \pm 0.94$ & $-9.43 p<0.001$ & $-1.94 p<0.01$ \\
\hline F. sylvatica cluster B & 29 & 7 & $0.47 \pm 0.11$ & 4.84 & $0.0096 \pm 0.02$ & $0.07 \pm 0.14$ & $-1.18 \mathrm{~ns}$ & $-1.15 \mathrm{~ns}$ \\
\hline
\end{tabular}

Standard and molecular indexes of the F. sylvatica cluster A and F. orientalis complex as determined by the network of haplotypes (see Fig. 4 and text). Symbols used: $n$, sample size; $\mathrm{k}$, number of different haplotypes; $\mathrm{H}$, genetic diversity; Ar, allelic richness calculated with a rarefaction size of 20 ; $\pi$, nucleotide diversity; MPD, mean number of pairwise difference; ns, not significant. 
One general observation within Fagaceae is that sequence divergence among and within genera is fairly low. This is based on a variety of sources, including the cpDNA genes, $r b c L, \operatorname{trnK}$ and $\operatorname{matK}[34,38,39]$, and the ITS region $[7,13]$. The various noncoding regions of cpDNA sequenced in this study also reveal appreciably low levels of sequence divergence between disjoint species of most of the Fagus species. Estimating divergence times between species with low sequence divergence can be problematic because of low statistical power of relative rate tests and high levels of standard error [49-51].

Calculation of divergence times using the highest estimate of the rate of synonymous changes for $r b c L\left(3 \times 10^{-10}\right)$ in Fagaceae [38], calibrated using fossil data for the minimum divergence time of Castanea and Quercus (60 million years B.P.; see Crepet [2]), provides a rough guide to estimate divergence times based on the noncoding cpDNA sequences examined here.

We adopted a coalescent-based method specifically devised for recent divergence events [52], which takes also into account the contribution of gene flow subsequent to the divergence event.

For Fagus, where roughly equal amounts of nucleotide variation were obtained for cpDNA noncoding regions, we calculated divergence times using the same substitution rate across the total amount of sequence. Values are derived from two different mutation rates, slow and fast which refers to the overall substitution rate $\left(0.71 \times 10^{-10}\right)$ and the synonymous rate $\left(2.36 \times 10^{-10}\right)$ of Frascaria et al [38], respectively. This suggests minimum and maximum divergence between $F$. orientalis and $F$. sylvatica of about 1.7 million and 5.74 million years BP (Table 2).

Even using the slowest mutation rate, it turns out that the two species diverged recently. The method we adopted allowed us to exclude that the relative low amount of divergence can be attributed to an older event of splitting followed by moderate gene flow.

\section{Conclusion}

We can conclude that at the end of Tertiary period the ancestral $F$. orientalis complex was present in Italy, and that only at the beginning of the Pliocene F. sylvatica became differentiated from $F$. orientalis, slowly turning to a predominant role among the Fagus species in West Europe.

The analysis of DNA from samples dated before the Last Glacial Maximum, allowed us to provide a direct demonstration that this event dramatically affected the distribution of forest trees such as the beech.

To better understand how and why the F. sylvatica became predominant in comparison to $F$. orientalis in western Europe more extensive molecular study on fossils remains from different geographic area and from different ages is required, combining the results with palynological and paleoclimatic data.

\section{Methods \\ Samples}

Plant material

The number, distribution, source, and the GenBank accession numbers of trnL-trnF cpDNA region of individuals analysed are reported in Supplementary material (see Additional file 1).

Considering that the genetic variability and biogeography of these taxa, have been extensively studied [9-19], and that our purpose was to analyse the phylogenetic inference within this European group, we prefer to analyse as much populations as possible for each species in the attempt to adequately cover their wide natural range.

\section{Fossil material}

The fossil material was collected from sediments of the deep levels ranging from $48.97 \mathrm{~m}$ to $50.79 \mathrm{~m}$ of a drill, $59.95 \mathrm{~m}$ long (Figure 4). It was pulled up from the sea ground, located at $6.90 \mathrm{~m}$ below the sea level, near Bocca di Malamocco (lat. $45^{\circ} 20^{\prime} 00^{\prime \prime} \mathrm{N}$, long. $12^{\circ} 19^{\prime} 36^{\prime \prime} \mathrm{E}$ ), in a position corresponding to one of the three natural pas-

Table 2: Divergence times.

\begin{tabular}{lcc}
\hline & $\mathbf{t}(\mathbf{9 5} \% \mathbf{C l})$ & TMRCA \\
\hline 'F. orientalis complex' vs 'F. sylvatica': slow & $5,738,173(6,230,016-2,131,321)$ & $8,033,442$ \\
'F. orientalis complex' vs 'F. sylvatica': fast & $1,700,992(1,846,715-631,773)$ & $2,381,291$ \\
\hline
\end{tabular}

Estimated divergence times, $t$, between the group denoted as 'orientalis' and 'sylvatica' as defined on the basis of genetic information (see text and Figure 3). TMRCA is the estimated time to the most recent common ancestor of the two groups. Values are derived from two different mutation rates, slow and fast which refers to the overall substitution rate $\left(0.71 \times 10^{-10}\right)$ and the synonymous rate $\left(2.36 \times 10^{-10}\right)$ of Frascaria et al. [38], respectively. 
sages connecting the Venice Lagoon to Adriatic Sea [53]. Sediments were previously submitted to three kinds of observations by Calderoni et al [44]: palaeo-environmental analysis, radiocarbon dating, and palynological analysis to obtain information about vegetation and climate evolution in the investigated area. Palynological analysis was carried out on 49 levels, mainly including clay with peat and sand layers (Figure 4 ). The most conserved sediments, from the palynological point of view, were those consisting of peat and clay layers [44]. The extraction of "sporomorphs" were only performed from thirty-two samples according to the method described by BertolaniMarchetti [54].

\section{Ancient DNA analysis}

Authentication methods

DNA is generally present only in small amounts in ancient samples, and it is often damaged. Therefore, extreme pre- cautions are needed to minimize the risk of amplifying and typing modern contaminating DNA molecules. To maximize the probability of extracting and sequencing authentic DNA from the ancient samples, the strictest available standards were followed throughout this study.

We have applied the following criteria to authenticate any amplified DNA sequences recovered from fossil samples $[55,56]$.

Physically isolated work area. Fossil suspension and PCR were done in a working area sterilized by UV radiation and exclusively dedicated for this analysis. The investigators of the study wore body protection, gloves and face mask throughout the entire pre-PCR and PCR work.

1. Negative controls. PCR controls produced negative results.

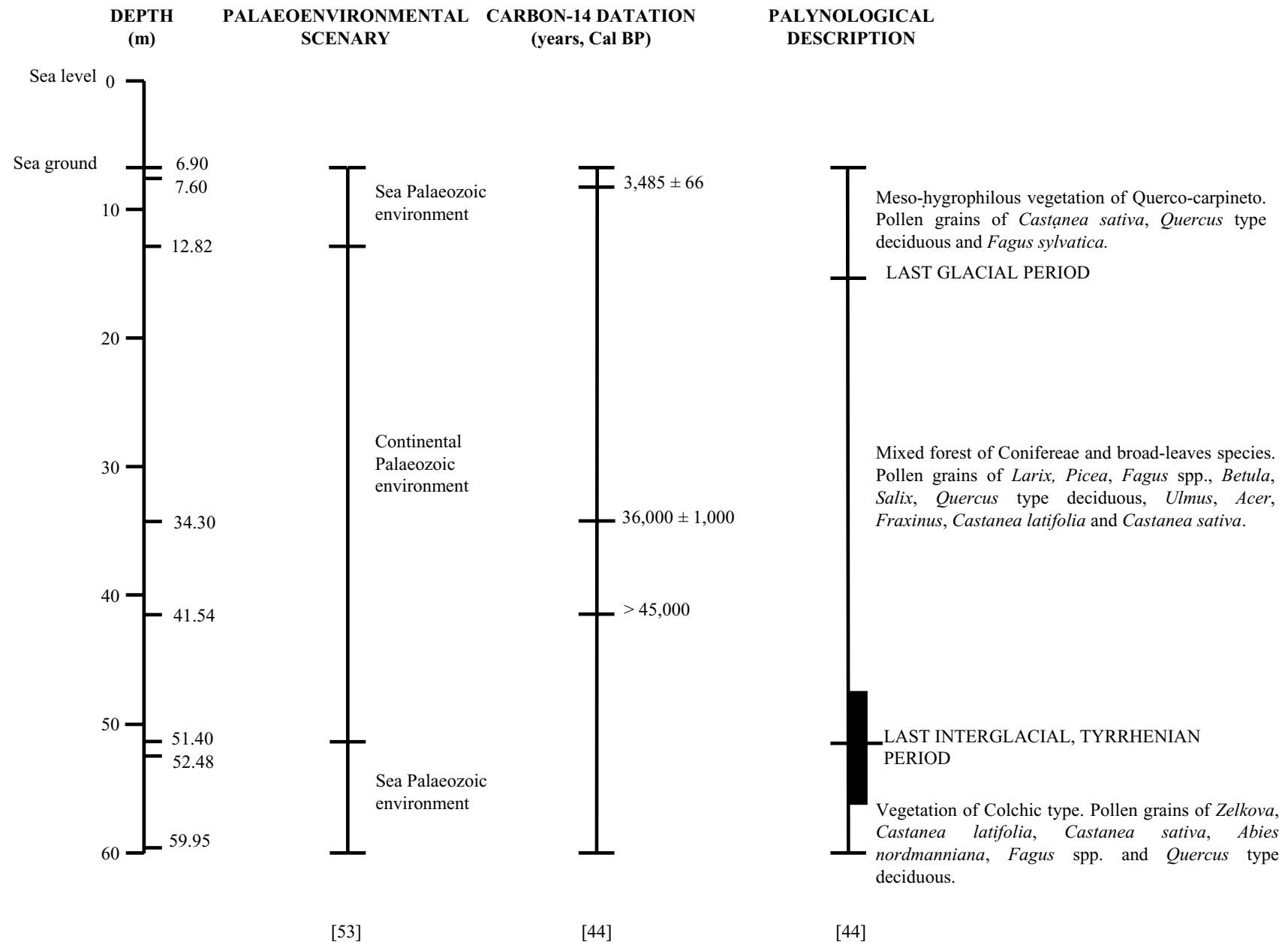

\section{Figure 4}

Data describing Bocca di Malocco. Description of the palaeo-environmental, radiocarbon and palynological data describing the Bocca di Malamocco (Venice Lagoon, Veneto, Italy) as summarized from Calderoni et al. [44]. 
2. Reproducibility. All results were identical in two independent laboratories.

3. Phylogenetic consistency. Amplified sequences showed unambiguous affinities with other Fagaceae sequences in a phylogenetic analysis, and therefore are phylogenetically consistent with their supposed Fagaceae origin.

4. Cloning. In total 57 clones were analysed and only 45 showed the expected fragment amplified. Therefore, 12 of 57 clones were excluded from the analysis as carrying partial or ambiguous fragments.

5. All results were identical in two independent extractions and two independent amplifications using four different overlapping primer pairs.

6. To explore if the number of templates was large enough $(>1000)$ to obtain reproducible results, a quantitative Real Time PCR experiment was performed on the $176 \mathrm{bp}$ fragment of the trnL-trnF chloroplast DNA (cpDNA) region.

All work was performed in isolated areas of Molecular Genetic Laboratory in Sesto Fiorentino (IGV-CNR) and in Molecular Anthropology Laboratory in Florence (DBAGUNIFI) where modern pollen DNA analysis have never been performed.

\section{In Molecular Genetic Laboratory (IGV-CNR, Sesto Fiorentino) \\ Preparation of fossil samples for amplification}

The working area, the disposable gloves, the automatic pipettes and all other material used for PCR were sterilised by exposition for $12 \mathrm{~h}$ to UV radiation (Atlas Germicidal Lamp of $30 \mathrm{~W}$ ) with an intensity maximum of $\lambda 254 \mathrm{~nm}$ at a distance of $67 \mathrm{~cm}$ from the working surface [57]. In addition, the laboratory is positively pressured to avoid the contamination with incoming external pollution (e.g., pollen, spores, etc.).

To diminish the steps in pre-PCR amplification, and, therefore, the possibility of contamination, a modified protocol respect to the one used by Suyama et al. [58] and by Parducci $e t$ al. [59], who crushed the pollen grains in PCR tube, was used.

The fossil pollen suspension was lysed by relying on temperature shock at high temperature as follow: $14 \mu \mathrm{l}$ of 10fold dilutions from the fossil pollen suspension were put in PCR tubes at $-20^{\circ} \mathrm{C}$ until completely frozen, lysed at $95^{\circ} \mathrm{C}$ for $10 \mathrm{~min}$, and then amplified by PCR.
Polymerase chain reactions (PCR) conditions for ancient pollen suspension

Amplifications were performed in a $20 \mu \mathrm{l}$ volume containing $10 \mathrm{mM}$ Tris- $\mathrm{HCl}$ ( $\mathrm{pH} 8.3$ ), $50 \mathrm{mM} \mathrm{KCl}, 1.5 \mathrm{mM}$ $\mathrm{MgCl}_{2}, 0.001 \%(\mathrm{w} / \mathrm{v})$ gelatin, $250 \mu \mathrm{M}$ of each deoxynucleoside triphosphate, $1 \mu \mathrm{M}$ of each primer, $14 \mu \mathrm{l}$ of pollen suspension, and $1 \mathrm{U}$ of Platinum Taq DNA polymerase (Invitrogen, CA, USA).

The 176 bp region was amplified using the following primers: 37 5' GAGCCAAATCCTATTTTC 3' - 215 5' ATGCTTTCTGTAGTTTTGAT 3'. After incubation for $60 \mathrm{~s}$ at $90^{\circ} \mathrm{C}$ and for $90 \mathrm{~s}$ at $95^{\circ} \mathrm{C}$, the reaction mixtures were subjected to different cycles by using the following temperature profiles: 1) $95^{\circ} \mathrm{C}$ for $30 \mathrm{~s}, 60^{\circ} \mathrm{C}$ for $30 \mathrm{~s}, 72^{\circ} \mathrm{C}$ for 4 min, for 5 cycles; 2 ) $95^{\circ} \mathrm{C}$ for $30 \mathrm{~s}, 55^{\circ} \mathrm{C}$ for $30 \mathrm{~s}, 72^{\circ} \mathrm{C}$ for $4 \mathrm{~min}$, for 5 cycles; and 3) $95^{\circ} \mathrm{C}$ for $30 \mathrm{~s}, 50^{\circ} \mathrm{C}$ for 30 $\mathrm{s}, 72^{\circ} \mathrm{C}$ for $4 \mathrm{~min}$, for 25 cycles. Amplification products were then incubated at $72^{\circ} \mathrm{C}$ for $10 \mathrm{~min}$. A Perkin Elmer 9700 thermocycler was used.

Amplification products ( $20 \mu \mathrm{l}$ per lane) were analyzed by gel electrophoresis on $1 \%(\mathrm{w} / \mathrm{v})$ agarose gel (Invitrogen, CA, USA) at $10 \mathrm{~V} / \mathrm{cm}$ for $2 \mathrm{~h}$ in Tris-acetate-EDTA buffer containing $0.5 \mu \mathrm{g} / \mathrm{ml}(\mathrm{w} / \mathrm{v})$ of ethidium bromide [60]. The gels were photographed and analyzed with an UVP scanner (Photo-Capt, Vilbert Coormat, France).

\section{Quantitative estimation}

The estimated copy number of chloroplast ancient DNA needs to be larger than the threshold value under which sporadic contamination can be excluded and allows assessment of the probability of its authenticity [43]. In this study, we quantified the $176 \mathrm{bp}$ cpDNA region.

The real-time PCR was carried out in a laboratory dedicated exclusively to fossil DNA work taking the necessary precautions as above.

Real-time PCR (qPCR) amplification was performed in 50 $\mu \mathrm{l}$ using DyNAMO ${ }^{\mathrm{TM}}$ SYBR $^{\circledR}$ Green qPCR Kit (FINNZYMES, Finland) in Chromo $4^{\mathrm{TM}}$ Real-Time PCR Detector (MJ Research, California, USA), and $0.5 \mu \mathrm{M}$ of the appropriate primers reported above. $2 \mu \mathrm{l}$ of diluted 1:200 DNA (extracted from fossil suspension material in the molecular anthropology laboratory) were incubated with $25 \mu \mathrm{l}$ master mix $(2 \times)$ (hot start version of a modified Tbr DNA polymerase, SYBER Green I, optimized PCR buffer, $5 \mathrm{mM}$ $\mathrm{MgCl}_{2}, \mathrm{dNTP}$ mix including dUTP) (Finnzymes, Finland) and $40 \mathrm{U} / \mathrm{ml}$ UDG.

Thermal cycling conditions were $50^{\circ} \mathrm{C}$ for 2 min (UNG treatment step): incubation with uracil- $N$-glycosylase (UNG) to remove the uracil residues from potentially contaminating DNA originating from previous amplifica- 
tions. This step was followed by an incubation at $95^{\circ} \mathrm{C}$ for 15 min for UNG denaturation and to activate $\mathrm{Tbr}$ DNA polymerase. Amplification was carried out for 60 cycles at $94^{\circ} \mathrm{C}$ for $45 \mathrm{~s}, 53^{\circ} \mathrm{C}$ for $1 \mathrm{~min}$ and $72^{\circ} \mathrm{C}$ for $1 \mathrm{~min}$, followed by melting curve step. Two serial 10 -fold dilutions (E10 to E0) of the same fragment (external standard), previously amplified and purified, were included in each experiment to generate the standard curve. The amplification efficiency of both standard and target molecules were identical. At least two no-template controls were included for each experiment.

\section{Cloning and sequencing}

The amplification products were purified using the Agarose Gel DNA Extraction Kit (Boehringer-Mannheim, Germany) following manufacturer's specifications. The 176 bp fragments, after gel purification, were cloned into plasmid vectors to randomly sample single molecules (Herrmann and Hummel 1984). The pCR $^{\circledR} 2.1$-TOPO vector (Invitrogen, CA, USA), and the $\mathrm{TOPO}^{\mathrm{TM}} \mathrm{TA}^{-}$Cloning ${ }^{\circledast}$ kit (Invitrogen, CA, USA) were used. Sequencing of the cloned fragments was performed in both directions from independent amplification reactions using the dideoxychain termination method [61], the Sequenase kit (USB) and the M13 universal primers.

The GenBank accession number of the $176 \mathrm{bp}$ fragment sequences is: DQ875545.

\section{In Molecular Anthropology Laboratory (DBAG-UNIFI, Florence) \\ DNA extraction}

DNA was extracted from fossil material by means of a silica based protocol (modified from Krings et al. [62]; see Caramelli et al. [63]); we performed two independent extractions. A negative control was included in each extraction.

\section{Amplification}

We amplify the a $157 \mathrm{bp}$ fragment of the $\operatorname{trn} \mathrm{L}-\operatorname{trn} \mathrm{F}$ cpDNA overlapping the $176 \mathrm{bp}$ region; the following primers were used: $175^{\prime}$ AATTAAAAATGGGCAATCCT 3' - 176 5' AATAACGTAACGAAGTCAACC 3'. The following profile was used to amplify $2 \mu \mathrm{l}$ of diluted 1: 200 DNA extracted from fossil material: $94^{\circ} \mathrm{C}$ for $10 \mathrm{~min}$ (Taq polymerase activation), followed by 50 cycles of PCR (denaturation $94^{\circ} \mathrm{C}$ for $45 \mathrm{~s}$; annealing $53^{\circ} \mathrm{C}$ for $1 \mathrm{~min}$; and extension $72^{\circ} \mathrm{C}$ for $1 \mathrm{~min}$ ) and a final step at $72^{\circ} \mathrm{C}$ for $10 \mathrm{~min}$. The $50 \mu \mathrm{l}$ reaction mix contained $2 \mathrm{U}$ of Ampli Taq Gold (Applied Biosystems), $200 \mu \mathrm{M}$ of each dNTP, and $1 \mu \mathrm{M}$ of each primer.

\section{Cloning and sequencing}

PCR products were cloned using the TOPO TA Cloning kit (Invitrogen), according to the manufacturer's instruc- tions. Screening of white recombinant colonies was accomplished by PCR. The colonies were transferred into a $30 \mu \mathrm{l}$ reaction mix $(67 \mathrm{mM}$ Tris $\mathrm{HCl}[\mathrm{pH} 8.8], 2 \mathrm{mM}$ $\mathrm{MgCl}_{2}, 1 \mu \mathrm{M}$ of each primer, $0.125 \mu \mathrm{M}$ of each dNTP, and $0.75 \mathrm{U}$ of $\mathrm{Taq}$ polymerase) containing M13 forward and reverse universal primers. After $5 \mathrm{~min}$ at $92^{\circ} \mathrm{C}, 30$ cycles of PCR $\left(30 \mathrm{~s}\right.$ at $90^{\circ} \mathrm{C}, 1 \mathrm{~min}$ at $50^{\circ} \mathrm{C}, 1 \mathrm{~min}$ at $\left.72^{\circ} \mathrm{C}\right)$ were performed and clones with an insert of the expected size were identified by agarose-gel electrophoresis. After purification of these PCR products with Microcon PCR devices (Amicon), a volume of $1.5 \mu \mathrm{l}$ was cycle-sequenced, according to the BigDye Terminator kit (Applied Biosystems) supplier's instructions. The sequence was determined using an Applied BioSystems 3100 DNA sequencer.

The GenBank accession number of the 157 bp fragment sequences is: $\underline{\mathrm{DQ} 875546}$.

\section{Modern DNA analysis}

\section{DNA extraction}

Total DNA was extracted from dormant buds, stored at $20^{\circ} \mathrm{C}$, using the DNeasy plant kit (QiAgen, Germany) following the manufacturer specifications.

\section{DNA amplification by PCR}

Amplifications were performed in a $20 \mu \mathrm{l}$ volume containing $10 \mathrm{mM}$ Tris- $\mathrm{HCl}(\mathrm{pH} 8.3), 50 \mathrm{mM} \mathrm{KCl}, 1.5 \mathrm{mM}$ $\mathrm{MgCl}_{2}, 0.001 \%(\mathrm{w} / \mathrm{v})$ gelatin, $250 \mu \mathrm{M}$ of each deoxynucleoside triphosphate, $1 \mu \mathrm{M}$ of each primer, $1 \mu \mathrm{l}(10 \mathrm{ng})$ of total DNA, and $1 \mathrm{U}$ of Platinum Taq DNA polymerase (Invitrogen, CA, USA). The oligonucleotides used as primers to amplify the trnL-trn $\mathrm{F}$ cpDNA region were the universal primers (c and d) described by Taberlet et al [64]. The PCR profiles are the same as above.

\section{Sequencing}

The amplification products were purified using the PCR DNA purification Kit (QiAgen, Germany) following supplier's instructions. Direct sequencing of amplified DNA was done in both directions from independent amplification reactions as above with the necessary modifications for direct PCR sequencing.

\section{Data analysis}

The $\operatorname{trn} \mathrm{L}$-trnF cpDNA sequences were multiply aligned, using the CLUSTAL-X program [65]. Alignments were verified and adjusted manually.

Phylogenetic inferences based on the cpDNA sequence were conducted with maximum parsimony [65], maximum likelihood, ML [67] and Bayesian, BI [68] methods.

The best-fit model of nucleotide substitution employed in the ML and BI analyses was selected using the Akaike 
Information Content [69] approach as implemented in Modeltest 3.7 [70].

In the MP and ML analyses we adopted the TBR (Tree Bisection Reconnection) branch-swapping algorithm with respectively 150 and 100 random addition-sequence replicates. Robustness of the phylogenetic trees generated by $\mathrm{MP}$ and ML was tested by using the non-parametric bootstrap [71] with 1000 pseudoreplicates. The above analyses were performed with the software package PAUP* ver. 4.0 [72]. The BI analyses were carried out with the program MrBayes ver. 3.0b4 [73]. The Monte Carlo Markov Chain length was 3,000,000 generations with a sampling frequency of 100 generations. The log-likelihood values for sampled trees were stabilized after almost 200,000 generations; we used the last 20,000 out of the 30,000 total trees to estimate Bayesian posterior probabilities. From these trees a 50\% majority-rule consensus tree was constructed with PAUP* ver. 4.0 [72].

The portion of the cpDNA (site 37 to site 215: $179 \mathrm{bp}$ ) amplified in the ancient sample was used to construct a statistical parsimony cladogram [74] within all the Fagus spp specimens. The statistical parsimony method joins all pairs of sequences that have a probability of parsimony greater than 0.95 , that is the probability of having no unobserved mutations. The cladogram was constructed with the TCS ver 1.21 software [75].

Genetic differentiation was assessed by means of $\Phi_{s t}$ (using the Kimura-2parameters distance method with gamma correction), the molecular analogue of conventional $\mathrm{F}_{s t}[76]$. We estimated Tajima's $D$ [77] and Fu's Fs [78] to test for neutrality. All the above analyses, together with standard and molecular indexes calculation, were run with the software package Arlequin ver 2.000 [79].

Allelic richness was calculated following the method described in Comps et al. [16].

Classical methods do not usually allow to distinguish whether a certain level of diversity between species/populations results from a recent divergence accompanied by limited migration, or from a long divergence time during which migration was substantial. A method that can explicitly deal with this feature is that developed by Nielsen and Wakeley [52]: this is a Markov Chain Monte Carlo coalescent-based approach for obtaining maximum-likelihood estimates of three population parameters, $\theta$ (which is equal to $4 \mathrm{~N}_{e \mu^{\prime}}$ where $\mathrm{N}_{\mathrm{e}}$ is the effective populations size and $\mu$ the mutation rate), $M$ (equal to $2 \mathrm{~N}_{\mathrm{e}} \mathrm{m}$, where $\mathrm{m}$ is the migration rate between two populations), and $T$ (equal to $t / 2 \mathrm{~N}_{e}$, where $t$ is the time since two populations diverged from the common ancestral population). Assuming no recombination and a demo- graphic model of two populations of equal effective size that split from a panmittic ancestral population at some time, $\mathrm{T}$, in the past, the method estimates the likelihood of the demographic parameters given the (i) demographic model, (ii) the data set (that is DNA sequences) and (iii) a mutational model. In our case we employed the finitesite Hasegawa, Kishino and Yano model (1985), which allows for recurrent mutations, differences in nucleotide frequencies and a transition/transversion bias. Adopting two mutation rates [38] we calculated $\mathrm{N}_{\mathrm{e}}$ and then we used this $\mathrm{N}_{\mathrm{e}}$ value to retrieve $\mathrm{T}$ and $\mathrm{M}$. To check the convergence of the ergodic averages we ran the program twice starting from different seed numbers.

\section{Competing interests}

The authors declare that they have no competing interests.

\section{Authors' contributions}

DP, CV2, LP and RG were involved in the design phase. LP provided most of the Fagus spp. samples. AP provided the fossil samples and the palynological data information. CV2 carried out the molecular genetics studies. DP and CV2 made the sequence alignment and drafted the manuscript. DP and CV4 performed phylogenetic and statistical analysis. DC and ML made the molecular reproducibility of fossil sample. DC, CV4, LP, AP, and RG have been involved in revising the manuscript for important intellectual content. All authors read and approved the final manuscript.

\section{Additional material}

\section{Additional File 1}

Table S1. A complete list of the population analysed for each species and related origin information with sequence accession number.

Click here for file

[http://www.biomedcentral.com/content/supplementary/1471-

2148-7-S2-S6-S1.pdf]

\section{Additional File 2}

Table S2. The multiple alignment of the $\operatorname{trn} L-\operatorname{trn} F$ among the difference species.

Click here for file

[http://www.biomedcentral.com/content/supplementary/14712148-7-S2-S6-S2.pdf]

\section{Additional File 3}

Table S3. The list of different haplotypes obtained in the parsimony network.

Click here for file

[http://www.biomedcentral.com/content/supplementary/1471-

2148-7-S2-S6-S3.pdf] 


\section{Acknowledgements}

The study was carried out, in part, with financial support from the Commission of the European Union (EU project FAIR3 CT96 I464) and from POM 2-SISIFOR-B28.

We thank Prof G. Mastromei (University of Florence, Italy), D. Gömöry (Zvolen, Slovakia), and Prof. C. Lalueza Fox (Universiti Pompeu Fabra, Barcelona, Spain) for English language revision and for helpful comments on the manuscript.

We express all our gratitude to A. M. Proietti (University of Florence, Italy), to Catia Boggi (IGV-CNR, Italy), the Italian Forest Service, M. Liesebach (Waldsieversdorf, Germany), P. Salehi Shanjani (Teheran, Iran), Z. Vardanyan (Yerevan, Armenia), M. Akhalkatsi (Thilisi, Georgia), A. Prokazin (Moscow, Russia), M. Pridnya (Sochi, Russia), I. Shvadchak (Lviv, Ukraine), P. Zhelev (Sofia, Bulgaria), D. Gömöry (Zvolen, Slovakia), S. McKeand (Raleigh, USA), J. Beaulieu (Quebec, Canada), K. Nagasaka (Ibaraki, Japan), and Z.-S. Kim (Seoul, Korea) for assistance during the material collection.

This article has been published as part of BMC Evolutionary Biology Volume 7 Supplement 2, 2007: Second Congress of Italian Evolutionary Biologists (First Congress of the Italian Society for Evolutionary Biology). The full contents of the supplement are available online at http://www.biomedcen tral.com $/|47|-2 \mid 48 / 7$ ? issue $=$ S2

\section{References}

I. Jones JH: Evolution of the Fagaceae: the implications of foliar features. Ann Mo Bot Gard 1986, 73:228-275.

2. Crepet WL: History and implications of the early North American fossil record of Fagaceae. In "Higher" Hamamelidae. Evolution systematics and fossil history of the Hamamelidae Volume 2. Edited by: Crane PR, Blackmore S. Clarendon: Oxford; 1989:23-44.

3. Manchester SR: Biogeographical relationships of North American Tertiary floras. Ann Mo Bot Gard 1999, 86:472-522.

4. Marchesoni V: Lineamenti paleobotanici dell'Interglaciale Riss-Würm nella Pianura Padana. N Giorn Bot ltal, n s 1960, 67:306-311.

5. Mancini F: Le variazioni climatiche in Italia alla fine del Riss dell'Olocene (Tentativo d'ordinamento cronologico). Boll Soc Geolog Ital 1962, 81:1-36.

6. Paganelli A: A palynological study of forest vegetation in the Veneto-Po Plain. Allionia 1996, 34:189-218.

7. Manos PS, Zhou Z-K, Cannon CH: Systematics of Fagaceae: phylogenetic tests of reproductive trait evolution. Int J Plant Sci 200I, I 62(6): I 36I-I379.

8. Whittemore TC, Schaal BA: Interspecific gene flow in sympatric oaks. Proc Natl Acad Sci USA I99I, 88:2540-2544.

9. Gömöry D, Paule L, Brus R, Zhelev P, Tomoviæ Z, Gračan J: Genetic differentiation and phylogeny of beech on the Balkan peninsula. J Evol Biol 1999, I 2:746-754.

10. Dumolin-Lapegue S, Demesure B, Fineschi S, Lecorre V, Petit RJ: Phylogeographic structure of white oaks throughout the European continent. Genetics I997, I46: I475-I487.

II. Petit RJ, Pineau E, Demesure B, Bacilieri R, Ducousso A, Kremer A: Chloroplast DNA footprints of postglacial recolonization by oaks. Proc Natl Acad Sci USA 1997, 94:9996-10001.

12. Tarbelet P, Gielly L, Pautou G, Bouvet J: Universal primers for amplification of three non-coding regions of chloroplast DNA. Plant Mol Biol I99I, I7:I I05-II09.

13. Manos PS, Doyle J], Nixon KC: Phylogeny biogeography and processes of molecular differentiation in Quercus subgenus Quercus (Fagaceae). Mol Phylogenet Evol 1999, I 2:333-349.

14. Villani F, Sansotta A, Cherubini M, Cesaroni D, Sbordoni V: Genetic structure of natural populations of Castanea sativa in Turkey: evidence of a hybrid zone. J Evol Biol I999, I 2:233-244.

15. Fineschi S, Taurchini D, Villani F, Vendramin GG: Chloroplast DNA polymorphism reveals little geographical structure in Castanea sativa Mill. (Fagaceae) throughout southern European countries. Mol Ecol 2000, 9:|495-I503.
16. Comps B, Gömöry D, Letouzey J, Thiébaut B, Petit RJ: Diverging trends between heterozygosity and allelic richness during postglacial colonization in the European beech. Genetics 2001 , I 57:389-397.

17. Petit RJ, Csaikl UM, Bordacs S, (29 co-authors), et al.: Chloroplast DNA variation in European white oaks Phylogeography and patterns of diversity based on data from over 2600 populations. For Ecol Man 2002, I 56:5-26.

18. Petit RJ, Aguinagalde I, de Beaulieu JL, (I 7 co-authors), et al.: Glacial refugia: hotspots but not melting pots of genetic diversity. Science 2003, 300: I563-1565.

19. Vettori C, Vendramin GG, Anzidei M, Pastorelli R, Paffetti D, Giannini $\mathrm{R}$ : Geographic distribution of chloroplast variation in Italian populations of beech (Fagus sylvatica L.). Theor Appl Genet 2004, 109:1-9.

20. Axelrod DI: Biogeography of oaks in the Arcto-Tertiary province. Ann Mo Bot Gard 1983, 70:629-657.

21. Daghlian CP, Crepet WL: Oak catkins, leaves and fruits from the Oligocene Catahoula Formation and their evolutionary significance. Am J Bot 1983, 70:639-649.

22. Crepet WL, Nixon KC: Earliest megafossil evidence of Fagaceae: phylogenetic and biogeographic implications. Am J Bot 1989, 76:842-855.

23. Crepet WL, Nixon KC: Extinct transitional Fagaceae from the Oligocene and their phylogenetic implications. Am J Bot 1989, 76:|493-1505.

24. Nixon KC, Crepet WL: Trigobalanus (Fagaceae): taxonomic status and phylogenetic relationships. Am J Bot I989, 6:828-84 I.

25. Herendeen PS, Crane PR, Drinnan AN: Fagaceous flowers, fruits and cupules from the Campanian (Late Cretaceous) of central Georgia, USA. Int J Plant Sci 1995, I 56:93-I I6.

26. Sims HP, Herendeen S, Crane PR: New genus of fossil Fagaceae from the Santonian (Late Cretaceous) of central Georgia, USA. Int J Plant Sci 1998, I 59:391-404.

27. Denk T: Phylogeny of Fagus L. (Fagaceae) based on morphological data. Plant Syst Evol 2003, 240:55-8I.

28. Forman LL: Trigobalanus a new genus of Fagaceae with notes on the classification of the family. Kew Bull 1964, I 7:38I-396.

29. Forman LL: Genetic delimitation in the Castanoideae (Fagaceae). Kew Bull 1966, I 8:42I-426.

30. Forman LL: On the evolution of cupules in the Fagaceae. Kew Bull 1966, I 8:385-419.

31. Tutin TG: Fagus L. In Flora Europea. Lycopodiaceae to Pltanaceae Volume I. Edited by: Tutin TG, Heywood VH, Burges NA, Valentine DH, Walters SM, Webb DA. Cambridge: Cambridge University Press; 1993.

32. Denk T, Grimm G, Stögerer K, Langer M, Hemleben V: The evolutionary history of Fagus in western Eurasia: Evidence from genes, morphology and the fossil record. Plant Syst Evol 2002, 232:213-236.

33. Paule L: Gene conservation in European beech (Fagus sylvatica L.). For Gene I995, 2(3): I6I-I70.

34. Manos PS, Stanford AM: The historical biogeography of Fagaceae: traking the tertiary history of temperate and subtropical forests of the northern hemisphere. Int J Plant Sci 200I, I 62(Suppl 6):S77-S93.

35. Denk T, Grimm GW, Hemleben V: Patterns of molecular and morphological differentiation in Fagus (Fagaceae): phylogenetic implications. Am J Bot 2005, 92(6): 1006-1016.

36. Paffetti D, Vettori C, Giannini R: Relict populations of Quercus calliprinos Webb on Sardinia island identified by chloroplast DNA sequences. For Genet 200I, 8(I): I-II.

37. Cech TR: Conserved sequences and structures of group I introns: building an active site for RNA catalysis. Gene 1988, 73:259-27I.

38. Frascaria N, Maggia L, Michaud $M$, Bousquet J: The rbcL gene sequence from chestnut indicates a slow rate of evolution in the Fagaceae. Genome 1993, 36:668-67I.

39. Manos PS, Steele KP: Phylogenetic analyses of "higher" Hamamelididae based on plastid sequence data. Am J Bot 1997, 84:|407-|4|9.

40. Manos PS, Nixon KC, Doyle J): Cladistic analysis of restriction site variation within the chloroplast DNA inverted repeat region of selected Hamamelididae. Syst Bot 1993, I 8:551-562.

4I. Kimura M: Estimation of evolutionary distances between homologous nucleotide sequences. Proc Natl Acad Sci USA I 98I, 78:454-458. 
42. Hofreiter M, Serre D, Poinar HN, Kuch M, Paabo S: Ancient DNA Nat Rev Genet 200I, 2(5):353-9.

43. Pruvost M, Geigl EV: Real time quantitative PCR to asses the authenticity of ancient DNA amplification. J Archaeol Science 2004, 3 I: II9I-I I97.

44. Calderoni GP, Curzi V, Paganelli A, Sartori E: Stratigraphic palaeoenvironmental preliminary results of Late Quaternary Gassy Sediments in Venice Lagoon [Abstract]. 5th International Conference on Gas Marine Sediments 1998:98-I0I.

45. Magri D: Quaternary History of Fagus in the Italian peninsula. Annali di Botanica 1998, LVI-I: 147-I54.

46. Follieri M, Magri D, Sadori L: 250,000-year pollen record from Valle di Castiglione (Roma). Pollen et Spores 1988, 30:329-356.

47. Nei TM, Chakraborty R: The bottleneck effect and genetic variability in populations. Evolution 1975, 29: I- I0.

48. Doebley J: Isozymic evidence and the evolution of crop plants. In Isozymes in plant biology Edited by: Soltis DE, Soltis PS. Portland, Oregon: Discorides Press; 1989:165-186.

49. Sanderson MJ: A nonparametric approach to estimating divergence times in the absence of rate constancy. Mol Biol Evol 1997, | 4:|2|8-|23|.

50. Schnabel A, Wendel JF: Cladistic biogeography of Gleditsia (Legunosae) based on $\mathrm{ndhF}$ and $\mathrm{rp} / \mathrm{l} 6$ chloroplast gene sequences. Am J Bot 1998, 85: I753-1765.

51. Wen J: Evolution of eastern Asian and eastern North American disjunct distributions in flowering plants. Annu Rev Ecol Syst 1999, 30:42I-455

52. Nielsen R, Wakeley J: Distinguishing migration from isolation: a Markov chain Monte Carlo approach. Genetics 200I, I 58(2):885-96.

53. Curzi PV, Fabiano M, Fava G: Gas and organic matter in Last Glacial and Holocene sediments of Venice lagoon. Chemistry and Ecology 1997, 14: I-20

54. Bertolani-Marchetti D: Metodo di preparazione dei sedimenti per l'analisi palinologica. Atti Soc Nat e Mat di Modena (Italia) 1960, 91:58-59.

55. Paabo S, Higuchi RG, Wilson AC: Ancient DNA and Polymerase Chain Reaction: the emerging field of molecular archaeology. J Biol Chem 1989, 264:9709-97I2.

56. Cooper A, Poinar HN: Ancient DNA: Do it reight or not at all. Science 2000, 289: I I39.

57. Herrmann B, Hummel S: Ancient DNA New York, USA: Springer Press; 1994.

58. Suyama $Y$, Kawamuro K, Kinoshita I, Yoshimura K, Tsumura Y, Takahara $\mathrm{H}$ : DNA sequences from a fossil pollen of Abies spp. from Pleistocene peat. Genes Genet Syst 1996, $71:$ : 145-149.

59. Parducci L, Suyama $Y$, Lascoux M, Bennett KD: Ancient DNA from pollen: a genetic record of population history in Scots pine. Mol Ecol 2005, I 4:2873-2882.

60. Sambrook J, Fritsch EF, Maniatis T: Molecular cloning. A laboratory Manual 2nd edition. New York: Cold Spring Harbor Laboratory; 1989.

61. Sanger F, Nicklen S, Coulson AR: DNA sequencing with chainterminating inhibitors. Proc Natl Acad Sci USA 1977, 74:5463-5467.

62. Krings M, Stone A, Schmitz RW, Krainitzki H, Stoneking M, Paabo S: Neandertal DNA sequences and the origin of modern humans. Cell I997, 90(I):19-30.

63. Caramelli D, Lalueza-Fox C, Vernesi C, (II co-authors), et al.: Evidence for a genetic discontinuity between Neandertals and 24,000-year-old anatomically modern Europeans. Proc Natl Acad Sci USA 2003, I 00(I I):6593-7.

64. Taberlet P, Fumagalli L, Wust-Saucy AG, Cosson JF: Comparative phylogeography and postglacial colonization routes in Europe. Mol Ecol 1998, 7:453-464.

65. Thompson JD, Gibson TJ, Plewniak F, Jeanmougin F, Higgins DG: The CLUSTAL-X windows interface: flexible strategies for multiple sequence alignment aided by quality analysis tools. Nucleic Acids Res 1997, 25(24):4876-4882.

66. Farris JS: Methods for computing Wagner trees. Syst Zool 1970 , 18:374-385.

67. Felsenstein J: Evolutionary trees from DNA sequences: a maximum likelihood approach. J Mol Evol 198I, 17:368-376.

68. Huelsenbeck JP, Rannala B, Larget. B: A Bayesian framework for the analysis of cospeciation. Evolution Int J Org Evolution 2000, 54:353-64.
69. Akaike $\mathrm{H}$ : A new look at the statistical model identification. IEEE Trans Aut Control 1974, 19:716-723.

70. Posada $D$, Crandall K: Modeltest: testing the model of DNA substitution. Bioinformatics 1998, | 4:8|7-8|8.

7I. Felsenstein J: Confidence limits on phylogenies: an approach using the bootstrap. Evolution 1985, 39:783-91.

72. Swofford D: PAUP*. Phylogenetics Analysis using Parsimony (*and other methods). Version 4.0b8 Sinauer, Sunderland, MA; 2000.

73. Huelsenbeck JP, Ronquist F: MrBAYES: Bayesian inference of phylogenetic trees. Bioinformatics 200I, I 7:754-55.

74. Templeton AR, Crandall KA, Sing CF: A cladistic analysis of phenotypic associations with haplotypes inferred from restriction endonuclease mapping and DNA sequence data. III. Cladogram estimation. Genetics 1992, 132:619-633.

75. Clement M, Posada D, Crandall KA: TCS: a computer program to estimate gene genealogies. Mol Ecol 2000, 9:1657-1659.

76. Excoffier L, Smouse P, Quattro JM: Analysis of molecular variance inferred from metric distances among DNA haplotypes: application to human mitochondrial DNA. Genetics |992, I 3 |:479-49|.

77. Tajima F: Statistical method for testing the neutral mutation hypothesis by DNA polymorphism. Genetics 1989, I 23:585-595.

78. Fu YX: Statistical tests of neutrality of mutations against populations growth, hitchhiking and background selection. Genetics 1997, 147:915-925.

79. Schneider S, Roessli D, Excoffier L: Arlequin ver 2.000. Dept. of Anthropology and Ecology. University of Geneve; 2000.
Publish with Bio Med Central and every scientist can read your work free of charge

"BioMed Central will be the most significant development for disseminating the results of biomedical research in our lifetime. "

Sir Paul Nurse, Cancer Research UK

Your research papers will be:

- available free of charge to the entire biomedical community

- peer reviewed and published immediately upon acceptance

- cited in PubMed and archived on PubMed Central

- yours - you keep the copyright
BiolMedcentral 